\title{
Vitamin C Ameliorates the Antifertility Effects of Inhaled Marijuana in Rats
}

\author{
Udokang Nsikak Ephraim, Udom Utibe Godwin
}

Department of Physiology, University of Uyo, Uyo, Nigeria

Email address:

nsikakudokang@yahoo.com (U. N. Ephraim)

\section{To cite this article:}

Udokang Nsikak Ephraim, Udom Utibe Godwin. Vitamin C Ameliorates the Antifertility Effects of Inhaled Marijuana in Rats. Science Journal of Public Health. Vol. 7, No. 5, 2019, pp. 140-150. doi: 10.11648/j.sjph.20190705.12

Received: May 20, 2019; Accepted: June 26, 2019; Published: September 25, 2019

\begin{abstract}
This study was carried out with a total of forty (40) male wistar rats randomly divided into four groups of ten (10) rats per group. Group 1 was the control and was treated with distilled water, group 2 was the low dose group (exposed to marijuana smoke for 5 minutes daily), group 3 was the high dose group (exposed to marijuana smoke for 10 minutes daily) and group 4 was the high dose + vitamin $\mathrm{C}$ group (exposed to marijuana smoke for 10 minutes and orally gavaged with vitamin $\mathrm{C}$ at $2.8 \mathrm{mg} / \mathrm{kg}$ body weight daily). The animals were sacrificed on the 29th day and testes were collected. Semen sample were collected and analyzed of Total sperm cell in sample (106/ml), Sperm Concentration (106/ml), Number of Motile sperm, Progressivity, Velocity of Active Path $(\mu \mathrm{m} / \mathrm{s})$. Testicular histology was carried out. The result showed a dose-dependent decrease in all the measured parameters in groups treated with marijuana (group 2 and 3) and an almost equivalent value with the control group for the group treated with marijuana + vitamin C (group 4). The testicular histological section reveals hypochromic section seminiferous tubules with swollen germinal cells and spermatogenic lining cell and irregular alignment of myoid cells for the group 2 and 3 when compared with the control group. But these damages were observed to be ameliorated in the marijuana + vitamin $\mathrm{C}$ group (group 4). From this result, it can therefore be concluded that marijuana possesses an antifertility property as seen in the decrease in total sperm count, Sperm Concentration, Number of Motile sperm, Progressivity, Velocity of Active Path and deformation of the testes of rats in this study. Also that vitamin C can ameliorate the antifertility effects of inhaled marijuana in rats.
\end{abstract}

Keywords: Marijuana, Vitamin C, Semen Analysis, Testicular Histology, Reactive Oxygen Specie (ROS), Antioxidant, Oxidative Stress, Antifertility

\section{Introduction}

The decline of male fertility in the general population has attracted increasing attention. Evidences include steadily progressing decline of sperm concentration [1], decline of sperm count [2], decline of semen quality [3], and decline of level of androgen [4]. Almost $15 \%$ of couples are unable to conceive after 1 year of regular unprotected intercourse, and in almost half of the cases, male infertility is the sole or a contributing factor [5].

Exposures to certain drugs, toxins, certain foods, environmental and biological factors have been implicated in male infertility. Alcohol, cigarette, caffeine, cocaine, opiods and marijuana used in this work have been reported to exhibit antifertility potential. These effects which may be short or long term posed serious threats to reproductive health and as such, study involving the possible remedy is of essence.

Marijuana also known as cannabis among other names is a drug in a mixed form of the leaves, stem, seeds and flower of the cannabis plant. Smoking is the most common route of marijuana exposure, and according to [6], this has been shown to have negative impact on male fertility, with an effect on hypothalamus-pituitary-gonadal axis, spermatogenesis, and sperm function, as cannabinoid receptors are expressed in the anterior pituitary, Leydig cells, Sertoli cells and in testicular tissues.

It is reported by Sansone et al. that among non-genetic causes of male infertility, oxidative stress resulting from exaggerated production of reactive oxygen species (ROS) is perhaps the most known factor [7]. Marijuana smoke is known to generate free radicals (Reactive Oxygen Species, ROS) [8] and possibly present its antifertility effect by this mechanism. 
With this, it is ofcourse in the right direction to consider ameliorating infertility in men by the use of an antioxidant and vitamin $\mathrm{c}$ (ascorbic acid) has proven to exhibit this property.

Vitamin $\mathrm{C}$ (ascorbic acid) is a required nutrient for a variety of biological functions [9]. Humans and other primates have lost the ability to synthesize ascorbic acid due to a defect in L-gulono-1,4-lactone oxidase, an enzyme that catalyzes the conversion of L-gulonolactone into ascorbic acid [9]. As an antioxidant, vitamin $\mathrm{C}$ provides protection against oxidative stress-induced cellular damage by scavenging of reactive oxygen species through vitamin Edependent neutralization of lipid hydroperoxyl radicals, and protection of proteins from alkylation by electrophilic lipid peroxidation products [10-12].

\subsection{Purpose of the Study}

This study sought;

1. To verify the anti-fertility effect of inhaled cannabis on male wistar rats using semen analysis and testicular histology as the criteria.

2. To investigate the ameliorating potential of vitamin $\mathrm{c}$ to these effects.

\subsection{Significance of the Study}

Infertility in men has become an area of concern as the number of cases increase globally and drug use is a contributing factor. As such, it is appropriate to research on possible remedy to men's infertility using antioxidant (vitamin c) as the case study on marijuana-induced infertility.

\section{Methodology}

\subsection{Drugs and Animal Collection}

\subsubsection{Marijuana}

An approval and sample of marijuana was gotten from The State Command, National Drug and Law Enforcement Agency (NDLEA), Akwalbom State Command, Uyo, for the study.

\subsubsection{Ascorbic Acid (Vitamin C)}

A packet of Emzor 100mg vitamin c tablets was bought from Leadsons Pharmacy in Uyo, AkwaIbom State.

\subsubsection{Animals}

Prepubertal rats of the Wistar strain (60-80g) were obtained from the animal house of the faculty of Basic Medical Sciences, University of Uyo and kept in wooden cages of $50 \times 30 \mathrm{~cm}$ dimension in a well-ventilated section of the same animal house for acclimatization. The animals were fed with rat chow (vital feed) and were allowed free access to drinking water while the experiment lasted.

\subsection{Experimental Design}

A total of forty (40) prepubertal male albino rats were randomly designed into four (4) groups of ten (10) animals per group with group 1 as control group. Group 2, 3 and 4 served as experimental group. Group 2 rats (low dose marijuana) were exposed to cannabis smoke through inhalation for 5 minutes a day. Group 3 rats (high dose marijuana) were exposed to cannabis smoke through inhalation for 10minutes a day. Group 4 (high dose marijuana + vitamin C) was exposed to cannabis smoke through inhalation for 10 minutes a day and vitamin C. Group 1 (control group) were given distilled water and feed throughout the experimental days.

\subsection{Administration}

\subsubsection{Marijuana}

Daily, animals from group 2, 3 and 4 were exposed to cannabis smoke. This was done by putting $1 \mathrm{~g}$ of the marijuana rolled with rizla rolling paper in a red-hot charcoal in a stainless plate and placing it in an airtight smoking chamber with 10 rats per smoking session for five (5) minutes. The procedure was repeated for the group 3 and 4 for another five (5) minutes each day, making the total time of exposure of this two groups (3 and 4) to be ten (10) minutes each day. The air-tight smoking chamber was made from polythene plastic cage of $60 \mathrm{~cm} \times 50 \mathrm{~cm} \times 40 \mathrm{~cm}$ dimension

\subsubsection{Vitamin $C$}

After the marijuana smoke exposure, the group 4 rats were orally gavaged with $2.8 \mathrm{mg} / \mathrm{kg}$ body weight of vitamin C.

\subsection{Sample Collection}

After 28 days of administration, the rats were anaethesized using chloroform and sacrificed, and the testes collected. Approval was gotten from the Local Research Ethical Committee of the University of Uyo, Uyo, AkwaIbom State, Nigeria.

\subsection{Analysis}

\subsubsection{Semen Analysis}

The cauda epididymis from each side of the testes were dissected out and several small cuts of about $1 \mathrm{~mm}$ made and the tissue suspended in $1 \mathrm{~m}$ of semen buffer solution to allow the spermatozoa to swim up. Semen analysis was carried out in accordance to the Breanna Tilley, 2007 and WHO (2015) criteria.

Freshly collected semen samples were collected and allow to liquefy at $37^{\circ} \mathrm{C}$. They diluted appropriately in mixed agglutination reaction (MAR) test buffer and the diluted sample were pipetted into a Makler chamber, which was placed on a heated microscope stage $\left(37^{\circ} \mathrm{C}\right)$. Video recordings were made from four different fields of the chamber using a 20x magnification objective on the microscope. Analysis was carried out based on capturing sequences of 64 frames per field and counting a minimum of 100 spermatozoa. The following measurements were obtained from the Total cell detected; these include Total sperm cell in sample $(106 / \mathrm{ml})$, Sperm Concentration $(106 / \mathrm{ml})$, Number of Motile sperm, Progressivity, Velocity of Active Path $(\mu \mathrm{m} / \mathrm{s})$. 


\subsubsection{Histological Analysis}

Testes were immediately immersed in Bouin's solution for fixation and processed until embedded in paraffin for histological analysis. Five micron thick sections were prepared using microtome (microTecLaborgerate $\mathrm{GmbH}$ Rudolf-Diesel-Straße, Walldorf, Germany) and stained using Hematoxylin and Eosin (H\&E) method. The specimens were examined under Olympus/3H light microscope-Japan.

\subsubsection{Statistical Analysis}

Data obtained were analyzed using means, standard error of mean, Analysis of Variance followed by Duncan's' test which was used to determine the direction of significance. The level of weight and hormones were reported in the form mean \pm SEM and statistical significance was established at 0.05 level of significance with $\mathrm{p}<0.05$ signifying significance. Data were analyzed using the Statistical Package for Social Sciences (SPSS version 22.0) and Graphpad Prism 5.0.

\section{Result}

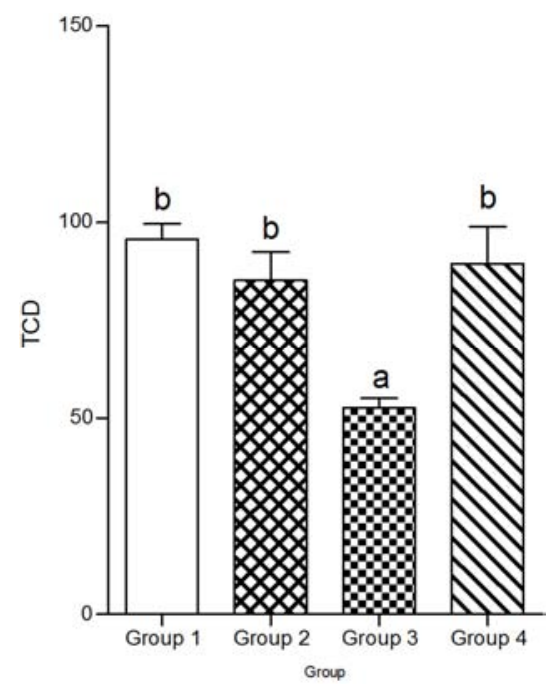

Figure 1. Comparison of Total sperm cell detected (TCD) (106/ml) in the Different Experimental Groups and the Control Group.

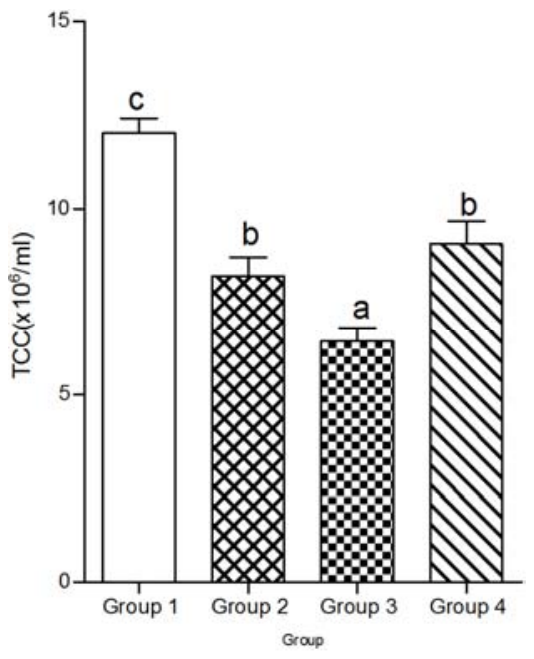

Figure 2. Comparison of Total Sperm cell concentration (TCC) (106/ml) in the Different Experimental Groups and the Control Group.

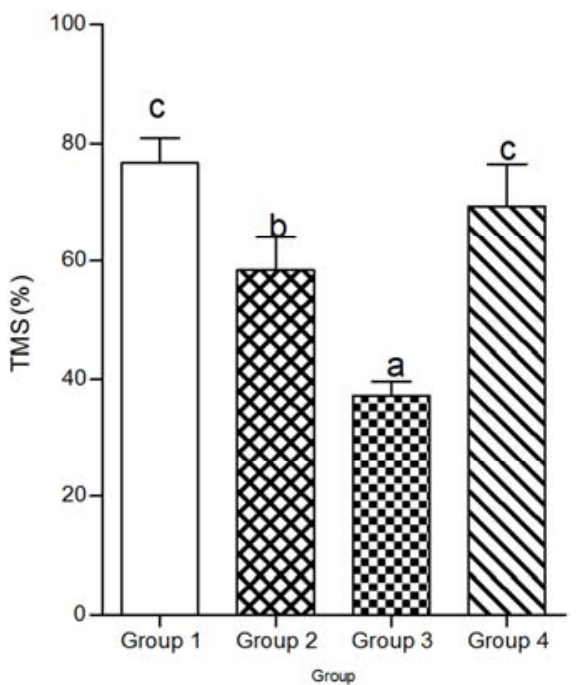

Figure 3. Comparison of Total number of motile sperm (TMS) in the Different Experimental Groups and the Control Group.

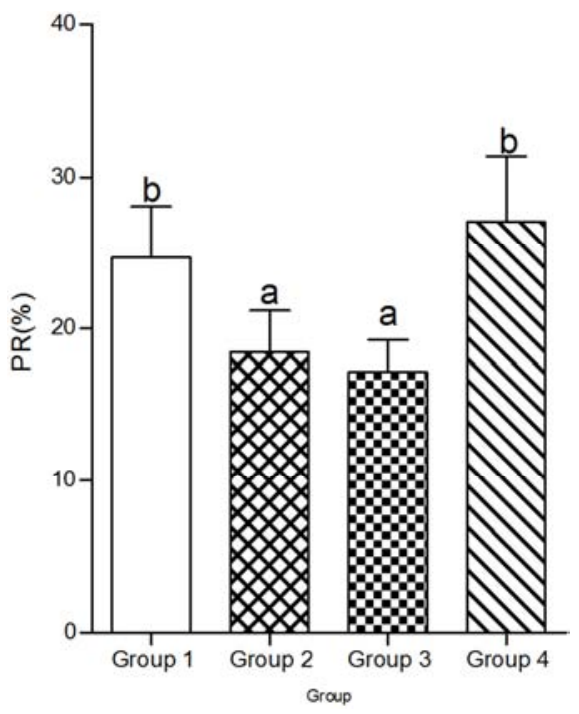

Figure 4. Comparison of Progressivity (PR) (\%) in the Different Experimental Groups and the Control Group.

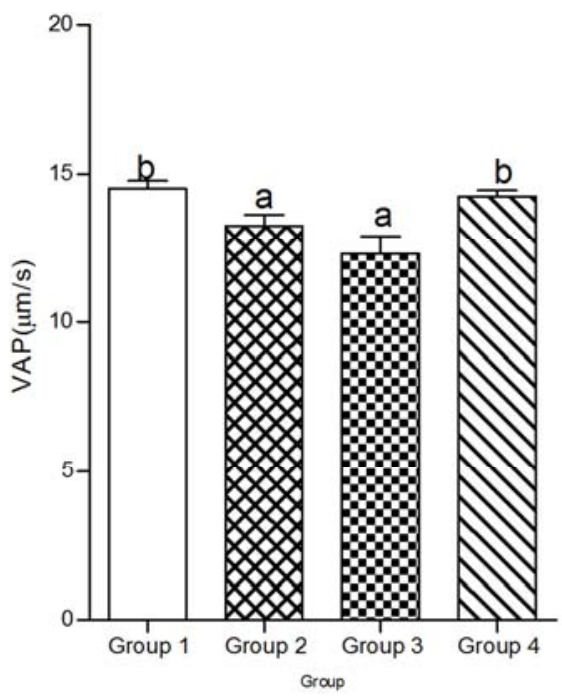

Figure 5. Comparison of Velocity of active path (VAP) $(\mu \mathrm{m} / \mathrm{s})$ in the Different Experimental Groups and the Control Group. 


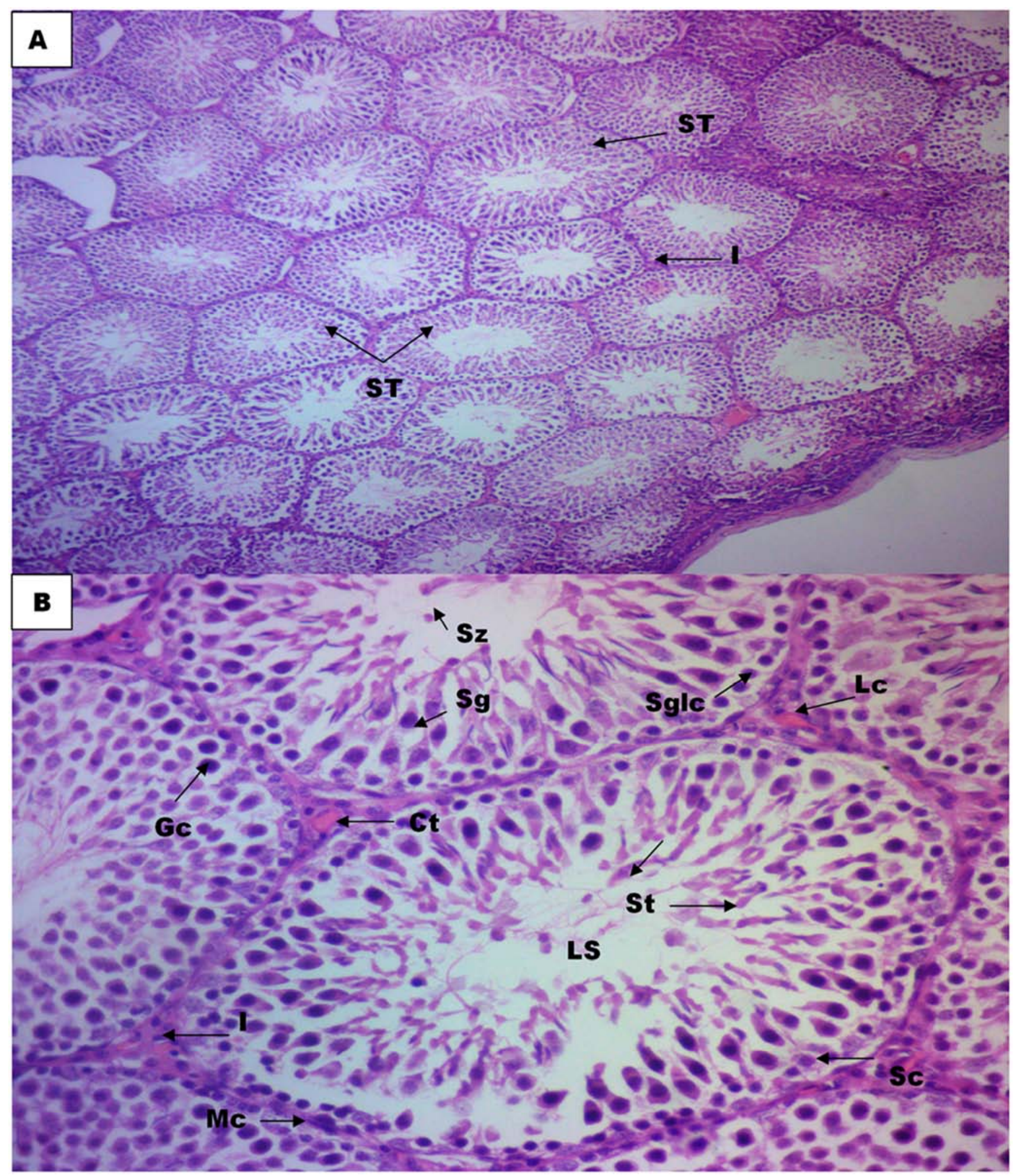

Figure 6. Photomicrographs of Control (Group 1) Testes without treatment stained with $H \& E$ method at Mag. A (X100) \& B (X400).

Keys: Seminiferous Luminal Tubules (ST), Germinal cells (Gc), Interstitium (I), Spermatogenic lining cells (Sglc), Myoid cells (Mc), Spermatocytes (Sp), Spermatids (St), Spertolic cells (Sc), Leydyg cells (LC) and Connective Tissue (Ct) 

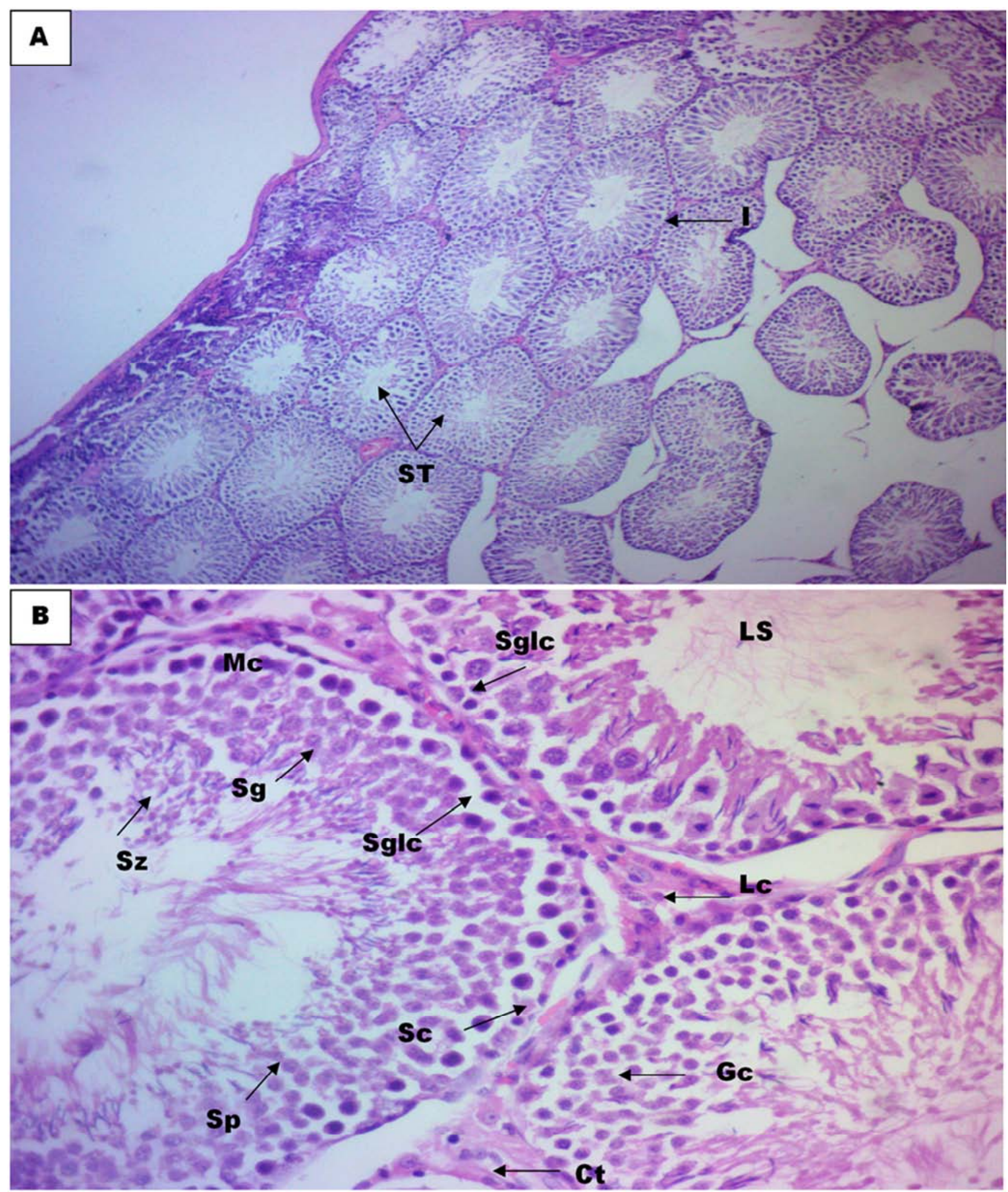

Figure 7. Photomicrographs of Testes treated with low dose marijuana (Group 2) stained with $H \& E$ method at Mag. A (X100) \& B (X400).

Keys: Seminiferous Luminal Tubules (ST), Germinal cells (Gc), Interstitium (I), Spermatogenic lining cells (Sglc), Myoid cells (Mc), Spermatocytes (Sp), Spermatids (St), Spertolic cells (Sc), Leydyg cells (LC) and Connective Tissue (Ct) 


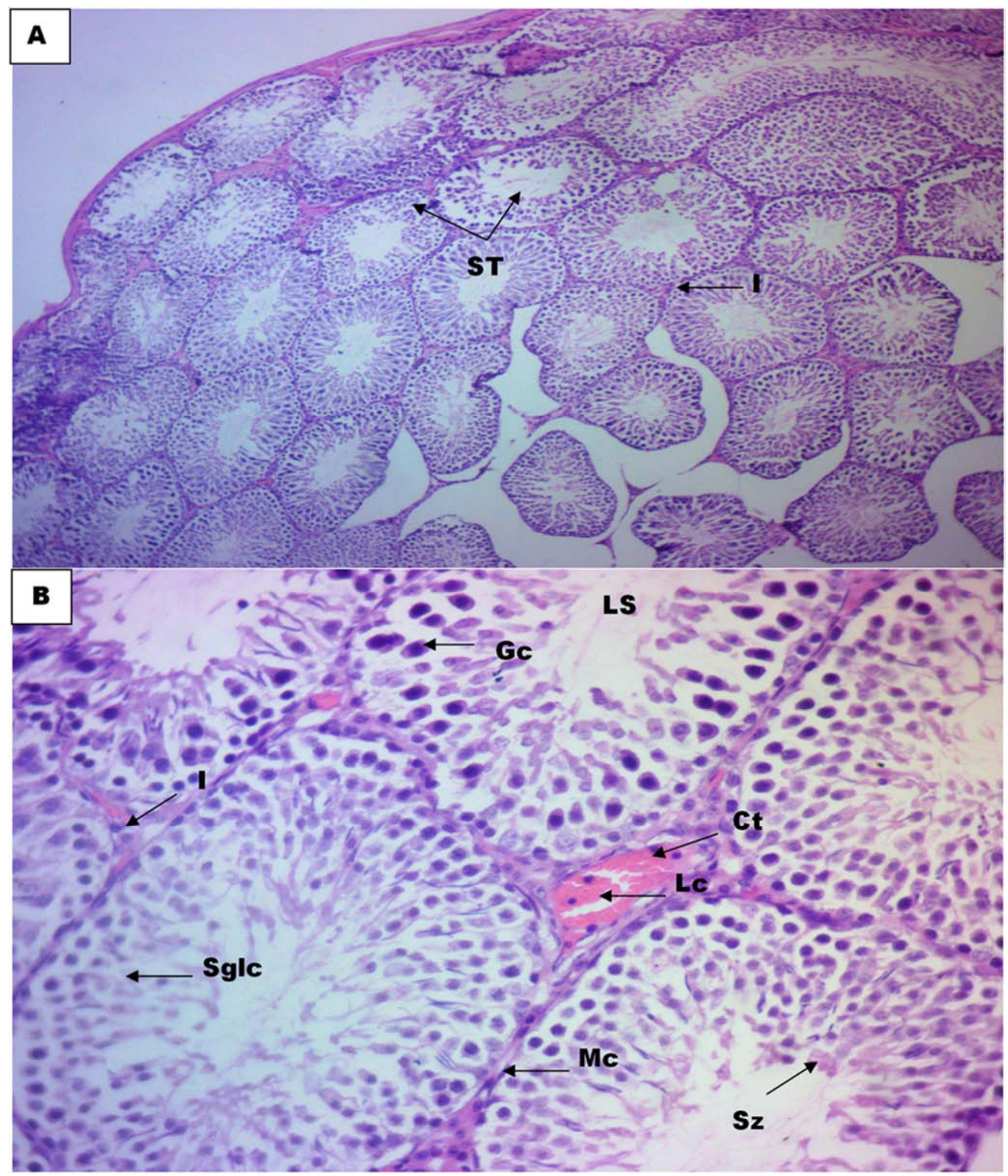

Figure 8. Photomicrographs of Testes treated with high dose marijuana (Group 3) stained with H \& E method at Mag. A (X100) \& B (X400).

Keys:Seminiferous Luminal Tubules (ST), Germinal cells (Gc), Interstitium (I), Spermatogenic lining cells (Sglc), Myoid cells (Mc), Spermatocytes (Sp), Spermatids (St), Spertolic cells (Sc), Leydyg cells (LC) and Connective Tissue (Ct) 


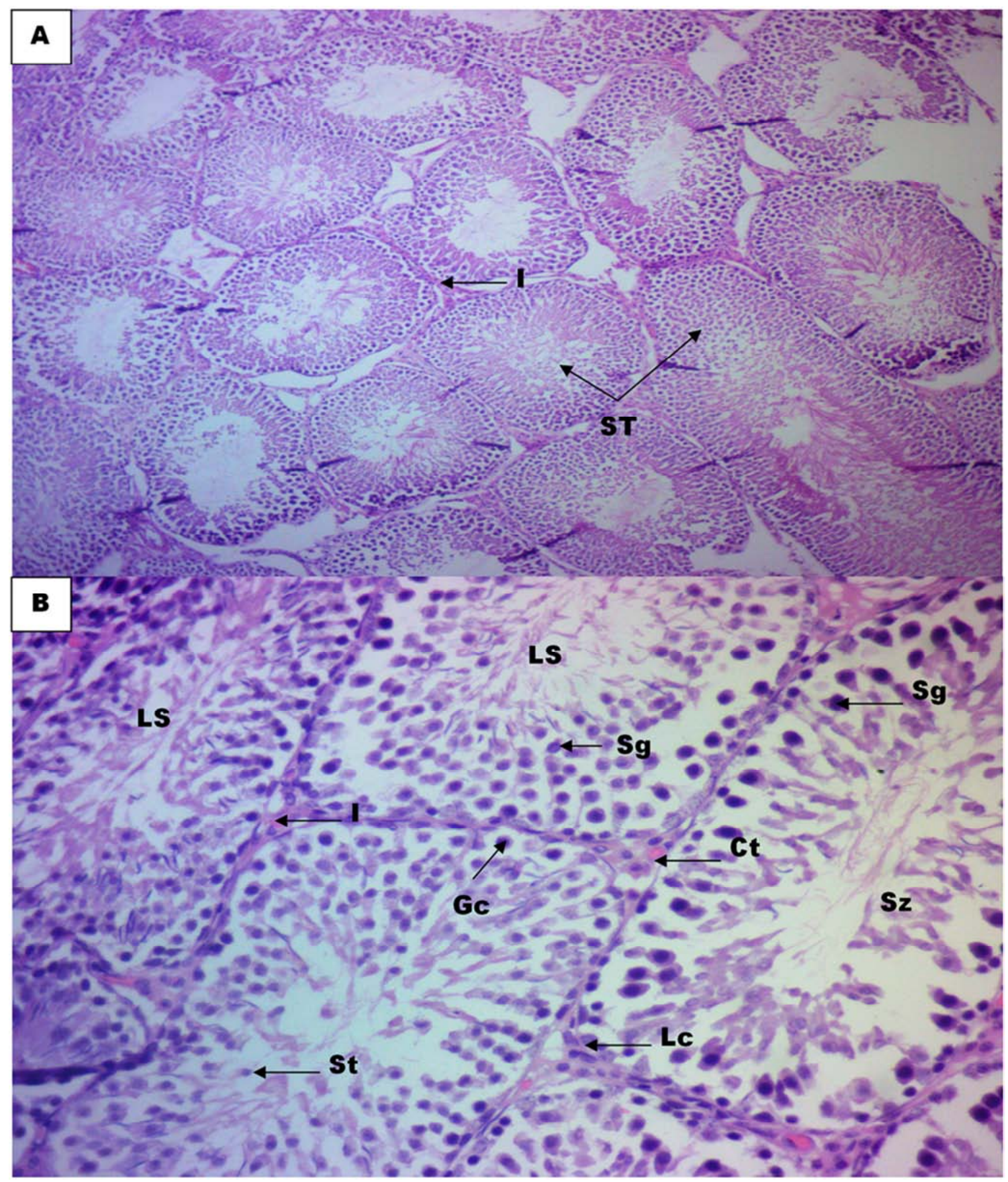

Figure 9. Photomicrographs of Testes treated with high dose marijuana + vitamin c (Group 4) stained with H \& E method at Mag. A (X100) \& B (X400).

Keys:Seminiferous Luminal Tubules (ST), Germinal cells (Gc), Interstitium (I), Spermatogenic lining cells (Sglc), Myoid cells (Mc), Spermatocytes (Sp), Spermatids (St), Spertolic cells (Sc), Leydyg cells (LC) and Connective Tissue (Ct) 
Table 1. Semen Analysis Results.

\begin{tabular}{lllll}
\hline Parameters & Group 1: (control) & $\begin{array}{l}\text { Group 2: (low dose } \\
\text { marijuana) }\end{array}$ & $\begin{array}{l}\text { Group 3: (high dose } \\
\text { marijuana) }\end{array}$ & $\begin{array}{l}\text { Group 4: (high dose } \\
\text { marijuana + vitamin c) }\end{array}$ \\
\hline Total sperm cell detected $(\mathrm{TCD})(106 / \mathrm{ml})$ & $95.67 \pm 3.93 \mathrm{~b}$ & $85.17 \pm 7.23 \mathrm{~b}$ & $52.50 \pm 2.49 \mathrm{a}$ & $89.50 \pm 9.42 \mathrm{~b}$ \\
Total Sperm cell concentration $(\mathrm{TCC})(106 / \mathrm{ml})$ & $12.01 \pm 0.49 \mathrm{c}$ & $8.02 \pm 0.50 \mathrm{~b}$ & $6.43 \pm 0.37 \mathrm{a}$ & $9.06 \pm 0.60 \mathrm{~b}$ \\
Total number of motile sperm $(\mathrm{TMS})$ & $76.67 \pm 4.25 \mathrm{c}$ & $58.33 \pm 5.74 \mathrm{~b}$ & $37.17 \pm 2.39 \mathrm{a}$ & $69.33 \pm 7.20 \mathrm{c}$ \\
Progressivity $(\mathrm{PR})$ & $24.68 \pm 3.41 \mathrm{~b}$ & $18.48 \pm 2.70 \mathrm{a}$ & $17.14 \pm 2.13 \mathrm{a}$ & $27.07 \pm 4.31 \mathrm{~b}$ \\
Velocity of active path $(\mathrm{VAP})(\mu \mathrm{m} / \mathrm{s})$ & $14.52 \pm 0.25 \mathrm{~b}$ & $13.25 \pm 0.37 \mathrm{a}$ & $12.31 \pm 0.57 \mathrm{a}$ & $14.25 \pm 0.19 \mathrm{~b}$ \\
\hline
\end{tabular}

Values reported in the form Mean \pm SEM. Similar superscript letters mean not significantly different $(\mathrm{p}>0.05)$ while different superscript letters mean significantly different $(\mathrm{p}<0.05)$.

Group 1 (Control): Histologic section of the Testes without treatment at magnification $\mathrm{A}(\mathrm{x} 100)$ and $\mathrm{B}(\mathrm{x} 400)$ revealed normal cellular profile of semiferoustubles, sertolic cells, spermatogenic lining cells, leydyg cells, germcells, lining myoid cells, spermatonia, spermatocytes and spermatids all within normal cellular archicteture without ay form of abnormality.

Remark: Not affected

Group 2 (Low dose Marijuana): Histologic section of the Testesat magnification A (x100) and B (x400) revealed hypochromic section of seminiferous tubules with swollen germinal cells and spermatogenic lining cell and irregular alignment of myoid cells when compared to control group.

\section{Remark: Moderately affected}

Group 3 (High dose Marijuana): Histologic section of the Testes at magnification $\mathrm{A}(\mathrm{x} 100)$ and $\mathrm{B}(\mathrm{x} 400)$ revealed hypochromic section seminiferous tubules with swollen germinal cells and spermatogenic lining cell and irregular alignment of myoid cells when compared to control group

Remark: Moderately affected

Group 4 (High dose Marijuana + vitamin C): Histologic section of the Testes at magnification A (x100) and B (x400) revealed hypochromic section of seminiferous tubules with slight swollen germinal cells and spermatogenic lining cell and irregular alignment of myoid cells however cellular components are fully present when compared to control group.

Remark: Slightly affected

\section{Discussion}

The increase in the cases of men infertility is now a well documented fact; but its remedy seems unspecified since there have been many reported causes and as such remedy appears uncertain.

The association of oxidative stress with the etiology of male infertility has been well established in many studies [13-17]. According to Sansone et al., among non-genetic causes of male infertility, oxidative stress resulting from exaggerated production of ROS is perhaps the most known factor in male infertility [7]. Colavitti et al. wrote that often, abnormal spermatozoa frequently display typical features of oxidative stress i.e. excessive levels of reactive oxygen species (ROS) [18] and Mayorga-Torres et al. included that it is associated with depleted antioxidant capacity [19].

Though the mechanism of marijuana induced infertility is said to be unclear, the correlation between marijuana smoke and increased ROS causing oxidative stress is being implicated in male infertility. This makes oxidative stress a possible factor in marijuana induced infertility.

Physiologically, sperm capacitation, hyperactivation, acrosome reaction, and sperm-oocyte fusion require low and controlled concentrations of ROS for the regulation of normal sperm functions [20]. Therefore, a balance called oxidative stress status normally exists between ROS production and antioxidant scavenging system in the male reproductive tract [21]. An overproduction of ROS in semen can overwhelm the antioxidant defense mechanisms of spermatozoa and seminal plasma, causing oxidative stress.

The total sperm cell detected decreases as duration of daily marijuana inhalation increases in this study. This implies that increase in duration or amount of marijuana smoke has negative effect on sperm count. Agarwal et al. reported that in normal condition, abnormal sperm cells are eliminated from the semen by apoptosis, but in the case of excessive ROS production (as suggested in this study), more sperm cells are affected, leading to the decrease in their number and implicitly to the lowering of fertility [22].

Kobayashi and Suda revealed that significant positive correlation between level of reactive oxygen species (ROS) and percentage of spermatozoa with many kinds of abnormalities like, abnormal heads, acrosome abnormalities, mid piece anomalies, cytoplasmic droplets and tail defects [23]. This of course could be related to the decrease in total percentage of sperm as observed in this study.

Sperm progressivity and velocity of active path are sperm parameters that are determined by sperm motility. In this study, a decrease in sperm motility is observed which could be the reason for the decrease in its progressivity and velocity of active path. The sperm cells are very rich in mitochondria because they constantly need an energy supply to maintain their motility. However, it is postulated by Alagbonsi and Olayaki that the main places of ROS generation in the sperm cell are mitochondria and the plasmatic membrane [24]. It has also shown that exposure of human spermatozoa to extracellular generated ROS induces a loss of motility that is directly correlated with the level of lipid peroxidation experienced by the spermatozoa [25]. The mammalian spermatozoa membrane is ROS susceptible, specifically because it contains high levels of lipids in the form of polyunsaturated fatty acids present in their plasma membrane [26], and negatively affecting sperm motility which is a 
function of its membrane. Kao et al. identified a highly significant correlation between oxidative stress and impaired sperm motility, as oxidation of sperm DNA result in reduced sperm motility [27].

The testicular histology result of this study confirms testicular damage by marijuana possibly by its apoptotic tendency and probably interfering with spermatogenesis. The histological section reveals hypochromic section seminiferous tubules with swollen germinal cells and spermatogenic lining cell and irregular alignment of myoid cells when compared to control group.

In this current study, the antifertility effect of marijuana has been explored in a bid to examine the potency of vitamin $\mathrm{C}$ in ameliorating this effect. Since oxidative stress induced by ROS production is one of the known factors in most disease conditions including male infertility. It is possible that an antioxidant like vitamin $\mathrm{C}$ which can reduce ROSinduced oxidative stress can be therapeutically useful in diseases where it is implicated in the etiology. This is observed in group 4 of this study, as seen vitamin C administered orally with $2.8 \mathrm{mg} / \mathrm{kg}$ body weight of rats ameliorated the antifertility effect of inhaled marijuana, by bringing the levels of the measured parameters in the experimental groups to almost the levels of the control groups.

Male infertility, as stated earlier has been reported to be associated with oxidative stress induced by ROS. It has been shown that among the causes of infertility which include, endocrine disorder, drugs, radiation and infection, all have been attributed to oxidative stress.

It is reported that high ROS levels can increase the possibility of infertility not only directly by inducing Oxidative Stress, but also indirectly by acting through the hypothalamic axes of hormone release [28, 29]. ROS reduce male sex hormone levels and disrupt the hormonal balance that regulates male reproductive functions [30], and thus causes infertility [31].

A study performed by Kiziler et al. on smokers revealed that the increased cadmium and lead concentrations in their blood and semen led to increased ROS production with an accompanying decrease in sperm motility [32]. CunhaOliveira et al. reported that oxidative stress caused by exposure to drugs of abuse may derive from direct or indirect effects, and may occur after drug exposure or during the withdrawal from the drug [33]. It has also been proven that prolonged exposure to tobacco smoke is linked to an increase in sperm DNA damage and apoptosis, leading to increased male infertility [34]. This may therefore be linked with the discovery of Lavranos et al. that some chemicals found in cigarettes cause an imbalance between ROS and antioxidants in the semen of smokers [35]. Accordingly, Agarwal et al. added that this ROS and antioxidant disproportion affects the overall semen quality [34]. As observed by Hacışevki, marijuana has also been proven to generate free radical (ROS) and implicated in male infertility [8].

De Iuliis et al. demonstrated in an invitro studies that electromagnetic radiation induces ROS production and DNA damage in human spermatozoa, which further decreases the motility and vitality of sperm cells as well as their concentration depending on the duration of exposure to radiation [36].

Ivanov et al. reported that in bacterial infections, oxidative stress arises atleast in part from altered metabolic pathways and has also been implicated in organ damage and the development of malignancies [37]. Infection of the semen with the bacterial microorganism Ureaplasma urealyticum is associated with increased seminal plasma viscosity and an increase in ROS production [38]. Acute and sub-acute infection and inflammation of the male gonads and accessory sex glands can be associated with disturbances in both sex gland function and sperm quality [39]. Elevated leukocytes and granulocytes which occur due to infection are believed to release various proinflammatory/bioactive cytokines, hydrogen peroxide, and other reactive oxygen species [40, 41]. Sikka added that these can cause oxidative stress and peroxidative damage to spermatozoa [42].

Rahman revealed that the structural modifications in the molecules of nucleic acids, proteins and lipids caused by increased concentration of reactive oxygen species (ROS) and/or reactive nitrogen species (RNS) lead to various metabolic changes that may contribute to the development of neurological diseases, cardiovascular diseases, cancer, among others [43]. It is also proposed by many that oxidative stress leads in the development of chronic and degenerative illnesses such as cancer, autoimmune disorders, aging, cataract, rheumatoid arthritis, cardiovascular, and neurodegenerative diseases [12, 44, 45].

With the reports of oxidative stress involvement in male infertility and other disease conditions, the use of an antioxidant in the management, prevention or treatment of these health problems could perhaps be a possible course to follow. Cunha-Oliveira et al. proposed that there is growing evidence that reversal of oxidative stress with antioxidants can reduce the degree of myocardial ischemic injury and heart dysfunction [33]. In that same manner and as observed in this current study, vitamin $\mathrm{C}$, an antioxidant ameliorates the antifertility effects of marijuana on rats. This however should be due to its antioxidative potential having the ability to donate a hydrogen atom and form a relatively stable ascorbyl free radical and probably reduce oxidative stress.

\section{Conclusion}

The increase in cases of male infertility cannot be overemphasized. Life styles, food, environmental, social and technological factors which are associated with stress are believed to be implicated in male infertility. Hence, investigation into every possible contributing or sole factor to this health problem should be an area of concern to scholars.

In this current study, marijuana has shown to be antifertile, impairing both the physiological and anatomical aspect of the reproductive organ, revealed in the seminalysis and testicular 
histopathology results respectively. Marijuana possibly presents its antifertility effects by generating Reactive Oxygen Specie (ROS) which causes oxidative stress and in turn damages the reproductive organ.

Oxidative stress has not only been implicated in male infertility but also in many other disease conditions.

An antioxidant, vitamin $\mathrm{C}$ ameliorated the antifertility effects of marijuana in rats in this study.

Accordingly, the use of vitamin $C$ therapeutically in male infertility and other diseases in which oxidative stress is implicated should be considered a viable measure.

\section{References}

[1] Lackner J, Schatzl G, Waldhör T, Resch K, Kratzik C, Marberger M. Constant decline in sperm concentration in infertile males in an urban population: experience over 18 years. Fertil Steril. 2005 Dec; 84 (6): 1657-61.

[2] Ajayi AB, Ajayi VD, Oyetunji I, Biobaku O, Aikhuele H, Adedamilola A, Ayelehin I I, Afolabi BM. Are semen parameters worsening? Comparing semen parameters 10 years apart. Niger Med J 2017; 58: 72-5.

[3] CendrineGeoffroy-Siraudin, Anderson DieudonnéLoundou, Fanny Romain, VincentAchard, BlandineCourbière, MarieHélène Perrard, Philippe Durand, Marie-RoberteGuichaoua. Decline of semen quality among 10932 males consulting for couple infertility over a 20-year period in Marseille, France. Asian J Androl. 2012; 14: 584-590. doi: 10.1038/aja.2011.173.

[4] Thomas G. Travison, Andre B. Araujo, Amy B. O'Donnell, VarantKupelian, John B. McKinlay, A Population-Level Decline in Serum Testosterone Levels in American Men, The Journal of Clinical Endocrinology \& Metabolism, Volume 92, Issue 1, January 2007, Pages 196-202, https://doi.org/10.1210/jc.2006-1375.

[5] Sharlip ID, Jarow JP, Belker AM, Lipshultz LI, Sigman M, Thomas AJ, Schlegel PN, Howards SS, Nehra A, Damewood $\mathrm{MD}$, et al. Best practice policies for male infertility. FertilSteril. 2002; 77 (5): 873-82.

[6] du Plessis SS, Agarwal A, Syriac A. Marijuana, phytocannabinoids, the endocannabinoid system, and male fertility. J Assist Reprod Genet. 2015; 32 (11): 1575-88.

[7] Sansone, A., Di Dato, C., de Angelis, C., Menafra, D., Pozza, C., Pivonello, R., and Gianfrilli, D. (2018). Smoke, alcohol and drug addiction and male fertility. Reproductive Biology and Endocrinology, 16 (1), 3.

[8] Hacışevki, A. (2009). An overview of ascorbic acid biochemistry. Journal of Faculty of Pharmacy. 38 (3): 233-255.

[9] Pehlivan, F. E. (2017). Vitamin C. An Antioxidant Agent. Vitamin C: 24-32.

[10] Verma, R. S., Mhta, A. and Srivastava, N. (2007). In vivo chlorpyrifos induced oxidative stress: Attenuation by antioxidant vitamins. Pesticide Biochemistry and Physiology. 88: 191-196.

[11] Rouhier, N., Lemaire, S. D. and Jacquot, J. P. (2008). The role of glutathione in photosynthetic organisms: Emerging functions for glutaredoxins and glutathionylation. Annual Review of Plant Biology. 59: 143-166.

[12] Bindhumol, V., Chitra, K. C. and Mathur, P. P. (2003). A induces reactive oxygen species generation in the liver of male rats. Toxicology. 188: 117-124.

[13] Aitken RJ. Oxidative stress and the etiology of male infertility. J Assist Reprod Genet. 2016; 33 (12): 1691-1692. doi: 10.1007/s10815-016-0791-4.

[14] H. Wagner, J. W. Cheng, E. Y. KoRole of reactive oxygen species in male infertility: an updated review of literature. Arab J. Urol., 16 (1) (2018), pp. 35-43.

[15] KeltonTremellen, Oxidative stress and male infertility-a clinical perspective, Human Reproduction Update, Volume 14, Issue 3, May/June 2008, Pages 243-258, https://doi.org/10.1093/humupd/dmn004

[16] Agarwal A, Prabakaran S, Allamaneni S (2006) What an andrologist/urologist should know about free radicals and why. Urology 67: 2-8.

[17] Mayorga-Torres BJ, Camargo M, Agarwal A, du Plessis SS, Cadavid AP, Cardona Maya WD (2015b). Influence of ejaculation frequency on seminal parameters. Reproductive biology and endocrinology: RB\&E 13: 47.

[18] Colavitti R, Pani G, Bedogni B, Anzevino R, Borrello S, Waltenberger J, Galeotti T (2002) Reactive oxygen species as downstream mediators of angiogenic signaling by vascular endothelial growth factor receptor-2/KDR. Journal of Biological Chemistry 277: 3101-3108.

[19] Mayorga-Torres BJ, Camargo M, Cadavid ÁP, du Plessis SS, Cardona Maya WD. Are oxidative stress markers associated with unexplained male infertility? Andrologia. 2016; doi: 10.1111/and.12659.PubMedGoogle Scholar.

[20] Saleh RA, Agarwal A. Oxidative stress and male infertility: from research bench to clinical practice. J Androl 2002; 23: 737-52.

[21] Sikka SC, Rajasekaran M, Hellstrom WJ. Role of oxidative stress and antioxidants in male infertility. J Androl 1995; 16: $464-8$.

[22] Agarwal A, Prabakaran SA, Said TM. Strategies to prevent oxidative stress-induced injury to human spermatozoa. J Androl 2005; 26: 654-60.

[23] Kobayashi CI, Suda T. Regulation of reactive oxygen species in stem cells and cancer stem cells. J Cell Physiol 2012; 227: 421-430.

[24] I. A. Alagbonsi, L. A. Olayaki. Ameliorative effect of combined melatonin and vitamin $\mathrm{C}$ on Cannabis sativainduced reproductive hormonal toxicity J. Afr. Assoc. Physiol. Sci., 4 (2016), pp. 14-24.

[25] Gomez E, Irvine D, Aitken R (1998) Evaluation of a spectrophotometric assay for the measurement of malondialdehyde and 4-hydroxy-alkenals in human spermatozoa: Relationships with semen quality and sperm function. International journal of andrology 21: 81-94.

[26] Aitken RJ, Smith TB, Jobling MS, Baker MA, De Iuliis GN (2014) Oxidative stress and male reproductive health. Asian journal of andrology 16: 31-38. 
[27] Kao SH, Chao HT, Chen HW, Hwang TI, Liao TL, Wei YH. Increase of oxidative stress in human sperm with lower motility. FertilSteril 2007. (30 July, 2007, online publication ahead of print).

[28] Diamanti-Kandarakis E, Bourguignon J-P, Giudice LC, Hauser R, Prins GS, Soto AM, et al. Endocrine-disrupting chemicals: an Endocrine Society scientific statement. Endocr Rev. 2009; 30 (4): 293-342.

[29] Spiers JG, Chen HJ, Sernia C, Lavidis NA. Activation of the hypothalamicpituitary-adrenal stress axis induces cellular oxidative stress. Front Neurosci. 2014; 8: 456.

[30] Appasamy M, Muttukrishna S, Pizzey A, Ozturk O, Groome $\mathrm{N}$, Serhal $\mathrm{P}$, et al. Relationship between male reproductive hormones, sperm DNA damage and markers of oxidative stress in infertility. ReprodBioMed Online. 2007; 14 (2): 15965 .

[31] M. Darbandi, S. Darbandi, A. Agarwal, P. Sengupta, D. Durairajanayagam, R. Henkel, M. R. Sadeghi Reactive oxygen species and male reproductive hormones Reprod. Biol. Endocrinol., 16 (2018), p. 87.

[32] Kiziler AR, Aydemir B, Onaran I, Alici B, Ozkara H, Gulyasar T, et al. High levels of cadmium and lead in seminal fluid and blood of smoking men are associated with high oxidative stress and damage in infertile subjects. Biol Trace Elem Res 2007; 120: 82-91.

[33] Cunha-Oliveira, T.; Rego, A. C.; Carvalho, F.; Oliveira, C. R. Medical Toxicology of Drugs of Abuse. Chapter 17, In Principles ofAddiction- Comprehensive Addictive Behaviors and Disorders, Miller, P., Ed.; Academic Press: 2013; Vol. 1, 159-175.

[34] Agarwal A, Virk G, Ong C, duPlessis SS: Effect of oxidative stress on male reproduction. World J Men's Health. 2014, 32: $1-17$.

[35] Lavranos G, Balla M, Tzortzopoulou A, Syriou V, Angelopoulou R. Investigating ROS sources in male infertility: a common end for numerous pathways. ReprodToxicol 2012; 34: 298-307.
[36] De Iuliis GN, Newey RJ, King BV, Aitken RJ. Mobile phone radiation induces reactive oxygen species production and DNA damage in human spermatozoa in vitro. PLoS One 2009; 4: e6446.

[37] Ivanov, A. V., Bartosch, B. \&Isaguliants, M. G. Oxidative Stress in Infection and Consequent Disease. Oxidative Medicine and Cellular Longevity 2017, 3496043, doi: $10.1155 / 2017 / 3496043$ (2017).

[38] Wang Y, Liang CL, Wu JQ, Xu C, Qin SX, Gao ES. Do Ureaplasmaurealyticum infections in the genital tract affect semen quality? Asian J Androl 2006; 8: 562-8.

[39] J. Derrick Jr, \& B. Dahlberg: Male genital infections and sperm viability. In: Human semen and fertility regulation in men. Ed: Hafez ESE, CV Mosby Co., NY 389-397 (1976).

[40] R. J. Aitken, K. M. West, D. W. Buckingham: Leoukocyte infiltration into the human ejaculate and its association with semen quality, oxidative stress, and sperm function. J Androl 15, 343- 352 (1994).

[41] M. Rajasekaran, W. J. Hellstrom, R. K. Naz, \& S. C. Sikka: Oxidative stress and interleukins in seminal plasma during leukocytospermia. FertilSteril 64, 166-171 (1995).

[42] Sikka SC. Oxidative stress and role of antioxidants in normal and abnormal sperm function Front Biosci. 1996; 1: 78-86.

[43] Rahman K. Studies on free radicals, antioxidants, and cofactors. Clinical Interventions in Aging. 2007; 2 (2): 219-236. PMCID: PMC2684512.

[44] Rouhier N Lemaire SD, Jacquot JP. The role of glutathione in photosynthetic organisms: Emerging functions for glutaredoxins and glutathionylation. Annual Review of Plant Biology. 2008; 59: 143-166. DOI: 10.1146/annurev.arplant.59.032607.092811. PMID 18444899.

[45] Verma RS, Mhta A, Srivastava N. In vivo chlorpyrifos induced oxidative stress: Attenuation by antioxidant vitamins. Pesticide Biochemistry and Physiology. 2007; 88: 191-196. 